\title{
The memory of a forgotten exile: Eugen Lozovan and the intellectual dissent
}

\section{Mircea-Cristian Ghenghea}

”Alexandru Ioan Cuza” University in Iaşi, e-mail: mcghenghea2010@yahoo.com

\begin{abstract}
Thirty years after the dissolution of the totalitarian regime in Romania, due to various reasons, most of the names of those who were forced to leave the country and choose the exile remained practically unknown to the general public, in spite of the fact that a good part of them contributed to the maintenance of a certain Romanian anti-communist resistance worldwide. One of these names is Eugen Lozovan, a distinguished scholar and a voice of the Romanian intellectual dissent from the end of the 1950s until the 1980s. Since the importance of his work as a linguist, historian, and philologist began to be widely acknowledged in his native country within the last decades, it seems of equal importance to consider his opposition towards the communist regime which controlled Romania from 1947 until 1989. He permanently took a stance and expressed his opinions through various texts published in Romanian periodicals from Western Europe, which necessarily add to the memory of the general intellectual anti-communist resistance. This is one of the reasons why in the present text we try to underline his figure and his contributions published in exile in order to better understand the significance and the impact they had for the Romanian intellectual dissent.

La treizeci de ani de la disoluția regimului totalitar din România din diferite motive majoritatea numelor celor care au fost obligați să părăsească țara și să aleagă exilul au rămas practic necunoscute publicului larg, în ciuda faptului că o bună parte a acestora au contribuit la menținerea unei anumite rezistențe anticomuniste românești pe plan internațional. Unul dintre aceste nume este cel al lui Eugen Lozovan, savant distins și o voce a disidenței intelectuale românești de la sfârșitul anilor '50 până în anii '80. Deoarece importanța activității sale ca lingvist, istoric și filolog a început să fie recunoscută pe scară largă în țara sa natală în ultimele decenii, pare să fie la fel de importantă abordarea opoziției sale față de regimul comunist care a controlat România din 1947 până în 1989. Acesta a fost permanent conectat la realitățile din țara pe care a părăsit-o și și-a exprimat părerile prin diferite texte apărute în publicații periodice românești din Europa de Vest, care se adaugă cu necesitate memoriei rezistenței intelectuale anticomuniste. Acesta este unul dintre motivele pentru care în textul de față încercăm să scoatem în evidența figura acestuia și să ne raportăm la materialele sale publicate în exil pentru a înțelege mai bine semnificația și impactul pe care l-au avut asupra disidenței intelectuale românești.
\end{abstract}

Keywords: Eugen Lozovan, Romania, Denmark, anti-communism, exile, intellectual dissent CC BY-SA License (https://creativecommons.org/licenses/by-sa/2.0)

This paper has been presented at the 10th International Conference on Baltic and Nordic Studies in Romania entitled Dissent versus Conformism in the Nordic, Baltic and Black Sea Areas, “Ovidius" University of Constanţa, 6-8 June 2019. 
Three decades after the events in December 1989, the Romanian society as a whole still has to find a way to properly understand and reconcile with its communist past. The process proves to be more than difficult as an important part of this past is still alive - people, habits, mentality. One of the consequences of this fact is that the segment represented by the Romanian anti-communist exile is far from being accurately acknowledged and appreciated for its role in fighting the totalitarian regime from Bucharest. Within this exile, a key role naturally belonged to the intellectuals who managed to flee Romania in late '40s and in the following decades.

Among these people who chose the exile instead of bearing the communist rule was also Eugen Lozovan. Regarded as "the most authentic modern follower of the example of Hasdeu"1, Lozovan was an outstanding representative of the Romanian intellectual generation of the second half of the $20^{\text {th }}$ century. His work in the fields of philology, linguistics, history show a thorough and daring scientist, who never forgot his origins and continuously discussed and criticized the communist regime back home.

Eugen Lozovan was born on May 2nd, 1929, in Bucharest, in a family with ancient Bessarabian traditions and connections². In 1947, after high school graduation as valedictorian he became a student at the Faculty of Letters and Philosophy of the University of Bucharest. A few years before, in 1942 , he had made his literary debut with a translation from Italian ${ }^{3}$. As a student at the university he had the chance of meeting great professors and specialists, like Iorgu Iordan, Umberto Cianciolo, Valeriu Papahagi. During the holidays he had to work, like thousands of other young men, as a brigadier on the Bumbeşti-Livezeni construction site. In 1950, helped by Marcel Fontaine, the head of the French Institute in Bucharest, he became a

\footnotetext{
${ }^{1}$ The Romanian quote is: "cel mai autentic continuator modern al exemplului hasdeian" - see Aurel Sasu, Dicționarul biografic al literaturii române, vol. I - A-L (Piteşti, 2006), 861. See also Victor Spinei, Reprezentanţi de seamă ai istoriografiei şi filologiei româneşti şi mondiale (Brăila, 1996), 365. Bogdan Petriceicu Hasdeu (1838-1907) is generally seen as the most important representative of the encyclopaedic spirit within the Romanian culture.

2 I. Oprişan, Repere biografice, in Eugen Lozovan, Dacia Sacra, Edition, biographical reference points, and profile sketch by I. Oprişan. Translation from English and French by Mihai Popescu. Second edition (Bucharest, 2005), 247. See also Elena Faur, Bogdan Harhătă and Nicolae Mocanu (coord.), „Profil bibliografic Eugen Lozovan (2 mai 1929 - 3 decembrie 1997)", Dacoromania, new series, XVIII, no. 2 (2013): 149.

${ }^{3}$ Faur, Harhătă and Mocanu.
} 
secretary of this institution. Towards the end of that year, on November 22 ${ }^{\text {nd }}$, he left for Austria as a translator of a students' delegation for the Council of the World Federation of the Democratic Youth. From Vienna, with French and Romanian help, he escaped the delegation and fled to Paris'. The '50s were dedicated to the successful completion of his studies - between 1950 and 1953 he studied at Sorbonne and Strasbourg as a scholarship student of the "Carol I" University Royal Foundation in Paris and the Free Europe College. As he confessed years later, he had the chance of meeting, studying, and working with great names of the Romanian exile and great Western professors, who influenced his intellectual formation and his personality: Sever Pop, Nicolae I. Herescu, Grigore Nandriş, Dumitru Găzdaru, Basil Munteanu, Petru Iroaie, Neagu Djuvara, Rosa del Conte, Raymond Bloch, Albert Dauzat, Jérôme Carcopino, Georges Dumézil, Franz Altheim, and others 5 . It was also the time when he began his prodigious activity not only as a scholar, but also as a commentator and publisher. In 1957 he started his didactic career in Denmark, at the University of Copenhagen. For 40 years, until his retirement in 1997, he represented a constant and valuable presence for the Romanian scientific life of the exile and not only. His intellectual and cultural profile reveals a complex personality, an erudite scholar of encyclopaedic formation and structure ${ }^{6}$. He passed away on December $3^{\text {rd }}$, 1997, after seeing again his native country twice, in 1996 and 1997.

Conceptually and methodologically wise, in the case of Eugen Lozovan, just like most of those intellectuals who fled Romania at the end of '40s, and then in the '50s and '60s, one might apply the ideas expressed by Leonidas Donskis when approaching the attitude manifested by the totalitarian regimes vis-à-vis the role of the intellectual within the new order institutionalized by these regimes: “Under totalitarianism, intellectuals can only survive either as marginalized mavericks or as underground dissenters. Yet, in both cases, they lose a broad public, and the public domain, essential things for making sense of their self-expression and self-fulfilment. Small wonder, then, that all great dystopias of the twentieth century - Yevgeny Zamyatin's We, Aldous Huxley's BraveNew World, George Orwell's 1984, and Anthony Burgess's A Clockwork Orange - have depicted an intellectual-free world of the imagined future. Advanced totalitarian technocracy allows no

\footnotetext{
${ }^{4}$ Oprişan, 248. As Eugen Lozovan confessed years later, he was helped by Marcel Fontaine and I.V. Emilian.

${ }^{5}$ Ibid., 249.

${ }^{6}$ Paola Polito, „Eugen Lozovan 1929-1997”, Revue Romane, vol. 33, 1 (1998): 4-6.
} 
room for intellectuals who are replaced by mental technicians, narrowminded experts, single-minded fanatics, functionaries, and specialists in brain-washing (all those qualities are almost perfectly embodied and combined in the character O'Brien from Orwell's 1984). Neither social critics/public dissenters not the classical type of scholar survive in the dystopian world"7. These assertions of the Lithuanian scholar reflect to the similarity the situation in Romania after 1947, when the communist regime began to brutally get rid of all inconvenient intellectuals (meaning all those who did not accept to conform and come to terms with the new realities). The concept of the "new man" and the predicted vision of the egalitarian society had no place for the intellectuals used to think freely and to understand the realities through a critical approach, and who were not falling easily for everything that the communist regime was trying to inoculate the peoples' minds with ${ }^{8}$. No wonder that, in a very plastic manner, certain authors speak about the contribution of the intellectuals at creating another Romania, a spiritual one, besides the geographical one ${ }^{9}$.

Next to the considerations expressed by Leonidas Donskis one should also consider the useful clarifications made by Dennis Deletant when approaching the general issue of the dissent - the dissident is represented by "a person who operates outside the system, who poses a challenge to it" and whose degree of opposition to a regime is necessarily greater than in a nonconformist ${ }^{10}$. With these specifications in mind one can easily affirm that

\footnotetext{
${ }^{7}$ Leonidas Donskis, Troubled Identity and the Modern World (New York, 2009), 167.

${ }^{8}$ Even in nowadays Romania the most widespread definition of the intellectual is highly influenced by the Marxist perceptions according to which an intellectual is represented by a "person who holds a diploma which sanctions or covers a certain intellectual capacity or ability acquired at the university"; yet, the main attribute of the intellectual is "the measure in which the critic use of the ration decants the social opinions. So the intellectual is the one who intervenes in the public debate in a critical way" - for further explanations and perspectives see Cristian Preda, Introducere în ştiinţa politică (Iaşi, 2013), 31-32.

${ }_{9}^{A}$ Au ales libertatea! Eds. Dumitru Dobre and Veronica Nanu (Târgovişte, 2015), 5: “Exodul, pe care destinul 1-a impus poporului român a făcut ca, alături de o Românie geografică, să ia naştere o Românie spirituală omniprezentă" / "The exodus which destiny imposed on the Romanian people gave birth to an omnipresent spiritual Romania besides a geographical one".

${ }^{10}$ Dennis Deletant, Romania, 1945-89: Resistance, Protest and Dissent, in Revolution and Resistance in Eastern Europe. Challenges to Communist Rule, Edited by Kevin McDermott and Matthew Stibbe (Oxford - New York, 2006), 90-91: “Before discussing 'dissent' in the Romanian context, some clarification of the meaning of the term is advisable. Several Romanian observers confuse dissent with nonconformism on the one hand, and with what they have called
} 
Eugen Lozovan generally fits the very idea of an intellectual dissident in exile, actively promoting his anti-communist ideas and opinions and permanently showing a critical approach of the Romanian realities.

His contributions in the fields of linguistics, classical philology, ancient and medieval history, lexicology, Romance and Germanic studies, etc. have been already underlined and integrated within the Romanian intellectual life of the last three decades ${ }^{11}$. To a certain extent, these were tacitly recognized and used even in the Socialist Romania, within the years previous to the events in December 198912. Several books and articles regarding his biography and scientific achievements have also been published after this date and played their part in finding his place in the Romanian cultural and academic life. However, beyond his scientific and literary accomplishments Eugen Lozovan represents a still little known reference point for the Romanian intellectual dissent from the beginning of the '50s until the middle of the '80s. His activity as a columnist, his texts referring to various persons and situations from the Socialist Republic of Romania prove not only a correct and clear understanding of the realities back home, but also a real talent as a journalist and pamphleteer. He was also one of the collaborators of the Romanian broadcasts of the French Radio. Here we can bring into attention the case of a text which should have been aired in May 1956 on Radio Paris to mark the passing of Ion Bianu, a respected philologist, academic, and former president of the Romanian Academy. For unknown reasons, but which can be easily guessed if we

\footnotetext{
'resistance through culture' on the other. I take a dissident to be a person who operates outside the system, who poses a challenge to it, whereas a nonconformist operates from within. Both express opposition to a regime, but the degree of opposition is greater in a dissident than in a nonconformist. Moreover, dissidence involves a public act, such as a protest, whereas nonconformism is a discreet stance. Nonconformist attitudes manifested by writers in the Ceauşescu period have been presented since 1989 as 'resistance through culture'. If we take 'resistance' to imply a public act, the term 'resistance through culture' is an inappropriate term for those who sought through their literary work to extend the boundaries of official tolerance, either by adopting a line considered by the authorities as ideologically suspect, or by highlighting certain contemporary social problems, or both".

${ }^{11}$ Spinei, 354-388. These pages can also be seen as recognition of the importance of Eugen Lozovan's work for the Romanian historiography and philology.

${ }^{12}$ Some of his scientific articles were quoted in various scientific periodicals of the Socialist Romania. See for instance Dan Ionescu, „Images du prince Dragoş dans les manuscrits de Moldavie au XVIII siècle", Revue des Etudes Sud-Est Européenes XIV, no. 4 (Octobre Décembre 1976): 631 - he uses the article „Rurik et Dragoş”, published by Eugen Lozovan in Revue des Etudes Roumaines XI-XII (1969): 61-80.
} 
consider the context created after the $20^{\text {th }}$ Congress of the Communist Party of the Soviet Union that took place in February same year, one of the editors of the Romanian program decided that the text should not be aired. It was rediscovered several years after the death of Eugen Lozovan and published in Romania, in $2006^{13}$.

The core of his journalistic and pamphleteer activity can be found in the pages of the publication "Stindardul", which appeared in Munich, West Germany, in 1953, thanks to Ion Valeriu Emilian ${ }^{14}$. From 1953 until $1984^{15}$ Lozovan was the main contributor of this gazette where he wrote more than 200 articles, notes, pamphlets, or simple annotations ${ }^{16}$. One should mention here that within the last years evidence was found that from the mid '70s, Ion Valeriu Emilian switched sides - from being a collaborator of the Western intelligence agencies he became a collaborator of the Romanian intelligence service ${ }^{17}$. At this point one cannot tell if this aspect was known to Eugen Lozovan and/or influenced in any way his articles dating from the last years of his collaboration with "Stindardul" (namely 1976-1984).

A strong and vivacious personality, Eugen Lozovan found himself in the middle of some polemics with other outstanding representatives of the

${ }^{13}$ Eugen Lozovan, "Comemorarea lui Ion Bianu”, Jurnalul literar. New series XVII, no. 7-12 (April - May - June 2006): 7. The text was sent by Lozovan to the Romanian Library in Freiburg, Germany, and this is why it was preserved and rediscovered.

${ }^{14}$ Ion Valeriu Emilian (1906-1985) was a sympathizer of the Romanian far-right movement and a member of the National-Christian Defense League (LANC - Liga Apărării Național Creştine) led by A.C. Cuza. As a military he fought on the Eastern front and in January 1945 chose to join the German army. After the occupation of Romania by the Red Army he decided to remain in exile and make an opposition to the communist regime in Romania. He is one of the persons who helped Eugen Lozovan to escape from Vienna in November 1950.

${ }_{15}$ Probably one of the main reasons that led to the end of his collaboration was the death of I.V. Emilian in 1985. The periodical continued to appear under the guidance of Ion Pantazi, son of Constantin Pantazi, minister for war during the Antonescu regime - William Totok and Elena-Irina Macovei, Între mit şi bagatelizare. Despre reconsiderarea critică a trecutului, Ion Gavrilă Ogoranu şi rezistenţa armată anticomunistă din România (Iaşi, 2016), 56.

${ }^{16}$ A list of all these texts can be found in Faur, Harhătă, Mocanu, 153-169. Besides his own name, he also used several pseudonyms to sign his texts: O.I. Mirea, Scutelnicul Adam, N. Chilianu, pamir, Ion Roşioru, Ţinecal (p. 152).

17 See for this Sorin Gabriel Ioniță, „Presa exilului românesc - componentă a patrimoniului național (1975-1989)", New Europe College Petre Țuțea Program Yearbook 2007-2008 (Bucharest, 2008), 183; Totok and Macovei, 55. Also Dinu Zamfirescu, Cârtiţele Securității. Agenți de influenţă din exilul românesc (Iaşi, 2013), 11-12. 
Romanian intellectual exile (Vintilă Horia ${ }^{18}$, Paul Miron ${ }^{19}$, Eugen Ionescu ${ }^{20}$, Mircea Eliade ${ }^{21}$, Virgil Ierunca ${ }^{22}$ ) or with intellectuals from the Socialist Romania (Mihail Sadoveanu ${ }^{23}$ ). The situation as such is not surprising and should not provoke any wonder. Historically wise, one might even talk about a tradition of division and disagreement specific to the Romanian exile from modern and contemporary periods, considering here, for instance, the situation following the revolutionary events of 1848-1849 in the Romanian

18 Vintilă Horia (1915-1991) was a writer and diplomat; in 1946 he was sentenced to life in prison by the communist authorities in Romania. He won the Goncourt Prize in 1960 for his novel God was born in exile (Dieu est né en exil).

${ }_{19}$ Paul Miron (1926-2008) was a linguist and philologist, the first professor of Romanian language and literature in West Germany (University of Freiburg). At least in the '50s, Miron and Lozovan were good friends as Paul Miron himself showed in one of his later books published in Romania - see Paul Miron, Măsura urmelor (Timişoara, 2000), passim.

${ }^{20}$ Eugen Ionescu (1909-1994) was a famous Romanian-French playwright, member of the French Academy (1970); in 1964 he was nominated for the Nobel Prize in Literature.

${ }^{21}$ Mircea Eliade (1907-1986) was a writer, philosopher, journalist, and the most famous Romanian historian of religion.

22 Virgil Ierunca (1920-2006) was a writer, literary critic, poet and journalist. The one who started the polemics was Eugen Lozovan - see his article "Conu Iancu \& Co.", Stindardul X, no. 64/65 (August - September 1962): 2. Ierunca answered in another Romanian periodical which appeared in Munich, "Cuvântul în exil” - Virgil Ierunca, „Năpasta”, Cuvântul în exil 6 (November 1962): 1, 3-4. Many years later, during a phone interview on September 17, 1998, Virgil Ierunca briefly approached the subject of his polemics with Eugen Lozovan, showing that the latter was excluded from the group of the collaborators of Radio Paris because of his extreme right attitude: "după câte îmi amintesc, s-au perindat prin faţa microfonului Constantin Brăiloiu, muzicologul de faimă mondială, [profesor de limba română de la Universitatea din Copenhaga] Eugen Lozovan, protejatul lui Marcel Fontaine. După ce a fost scos la pensie Marcel Fontaine, Lozovan a fost exclus pentru că devenise un extremist de dreapta; într-un ziar din Germania care se chema Stindardul a început să atace chiar şi pe marii clasici. Eu am polemizat cu el, atacase pe Maiorescu, atacase pe I.L. Caragiale, ca să nu mai vorbesc de E. Lovinescu" / "as far as I remember, in front of the microphone came Constantin Brăiloiu, the world class musicologist, [the professor of Romanian language at the University in Copenhagen] Eugen Lozovan, the protégé of Marcel Fontaine. After the retirement of Marcel Fontaine, Lozovan was excluded as he had become a far right extremist; in a newspaper in Germany which was entitled Stindardul he even began to attack the great classics. I polemicized with him, he had attacked Maiorescu, he had attacked Caragiale, not to mention E. Lovinescu". See Interviu cu scriitorul Virgil Ierunca din Arhiva Grupului de Istorie Orală al Radio România, conducted by Octavian Silvestru, accessible online at http://arhiva.rador.ro/info4.shtml?cat=1281\&news=338665, accessed in June 2019.

23 O.I. Mirea, „Nelegiurea Sadoveanului”, in Stindardul 10-11 (June - July 1954): 2. Mihail Sadoveanu (1880-1961) was a famous Romanian novelist and journalist; he was one of the intellectuals who did not flee Romania and conformed to the new communist regime. 
space. All the more was the case during the '60s, '70s, and '80s, when the communist regime back home tried and often succeeded to discord the Romanian exile.

With respect to Eugen Lozovan, probably the most well known case of polemics is the one concerning the vehement contestation of Emil Cioran ${ }^{24}$, which happened in 1973, following the publication in the previous year of a controversial book entitled Convorbiri cu Emil Cioran [Conversations with Emil Cioran], by the journalist François Bondy. Briefly, this is what the situation was all about - in the above mentioned book several interviews with the Romanian philosopher were published in which he denied any connection with the Romanian legionary movement characterized by him in a harsh and nonchalant manner: "As they say about cancer that it is more than a disease, but a complex of diseases, that was the case of the Iron Guard - a complex of movements and a demented sect rather than a party" 25 .

Although he had not been a member of the Iron Guard, Eugen Lozovan never hid his sympathies towards the legionary movement ${ }^{26}$ or marshal Ion Antonescu. This is clearly another reason one should consider when we try to explain his reaction to the words of Emil Cioran. Nevertheless, in the general plan of the exile, this sort of abjuration from the convictions that dominated or influenced the youth of many of the Romanian exiles might have been easily seen as an attempt to fraternize with the communist regime in order to obtain various gains or favours. Lozovan's reaction was prompt and trenchant. He publicly reneged Cioran and attacked him in one of his articles published in "Stindardul", on which occasion one could also see certain accents of anti-Semitism: "I wish to Emil Cioran, who for me has become a non-human, to be quoted with all the

\footnotetext{
${ }^{24}$ Emil Cioran (1911-1995) was a famous Romanian philosopher and writer.

${ }^{25}$ Mihai Pelin, „Adversarul lui Iisus”, Adevărul literar şi artistic XI, no. 628 (6 August 2002): 6. ${ }^{26}$ Marta Petreu supposes that Lozovan became a sympathizer of the movement during his years of exile - Marta Petreu, De la Junimea la Noica. Studii de cultură românească (Iaşi, 2011), 463: “Autorul, un lingvist român de o cultură consistentă, care s-a exilat în 1950 şi care, prin data naşterii, 1929, nu avea cum să aparţină legionarismului interbelic, trebuie să fi devenit filolegionar în exil. Eugen Lozovan l-a atacat deci pe Cioran în numele onoarei şi demnităţii legionare" / "The author [Eugen Lozovan - our note], a Romanian linguist of considerable culture, who exiled himself in 1950 and who, by his birth date, could not belong to the interwar legionarism, must have become a philolegionar in exile. So Eugen Lozovan attacked Cioran in the name of the legionary honour and dignity".
} 
honours in Scânteia and at the future world congress of Judaism"27. The quarrel continued in the following period, as former members of the Iron Guard in exile also reacted after the publication of the book, praising Lozovan for his attitude ${ }^{28}$.

Eugen Lozovan was a constant critic of the Soviet system and Russian influence in Europe and around the world, a fact that can be noticed not only in the pages of "Stindardul". Even in 1952, during an intervention which he had with the occasion of a Round Table Conference at the Institute of World Affairs in Geneva, he warned about the danger represented by communism and by Russia, stubborn opponents of freedom and of the free world ${ }^{29}$. In a time (the '60s) when many Western writers and intellectuals (especially in France and Italy) were playing the coquette with the left-wing ideology, he did not hesitate to take a stance contrary to this trend and blamed the gullibility and the naivety proven by persons like the French novelist and journalist Michel Droit, for example ${ }^{30}$.

The unfortunate destiny of the entire generation of Romanian intellectuals who had to flee Romania at the end of '40s and in the '50s and '60s was another subject that concerned Eugen Lozovan. In various texts he blamed and condemned in virulent terms the unscrupulous communist propaganda which glorified the achievements of socialism and the so-called deliberate contribution of the young Romanians to the growth of the country casting a wave of silence and forgetfulness over the Romanian elite destroyed after $1947^{31}$.

${ }^{27}$ E. Lozovan, „Pe culmile descreerării”, Stindardul, XXI, special edition, no. 124 B (July 1973): 1.

${ }^{28}$ Pelin, 7.

${ }^{29}$ "Rusia împotriva Europei”, Stindardul I, no. 2 (1953): 3. See also "Maica Rusie mântuitoare”, in Eugen Lozovan, Glose istorico-literare. Publicate în revista "Dorul", în anul 1994 (Aalborg, 1994), 77.

30 See the column entitled Scolii - E. Lozovan, "Scolii”, Stindardul XVI, no. 104 (September November 1968): 2. Michel Droit (1923-2000) was a French novelist and journalist; he became member of the French Academy in 1980.

${ }^{31}$ For instance, in a pugnacious and incisive text he attacked Miron Radu Paraschivescu, a well-known writer in Romania in the '60s and '70s, who, in the pages of the review "România literară" declared himself worried about the situation in Biafra, a self-proclaimed state in Africa. Naming him a "toad", Lozovan shows his contempt for Paraschivescu and others like him who were more preoccupied by the age limit in Africa rather than in the Romanian prisons where great names of the country were killed by communists. „Puțin îmi pasă de Biafra”, Stindardul XVI, no. 104 (September - November 1968): 1; „Bumbeşti-Livezeni”, 
Nevertheless, in the case of Eugen Lozovan the researchers of the Romanian intellectual dissent and of the Romanian anti-communist exile should consider taking into account all nuances of the prodigious activity of this effervescent and restless spirit. One must mention here not only his sympathies towards the Romanian far right movement, marshal Ion Antonescu, or his anti-Semitic stance which can be noticed within his polemics, but also certain allegations that appeared after 1989 and which place him, conceptually wise, among those who, because of the confusion provoked by the term "dissent", betrayed the real exile due to the fact that for many of the Romanian exiles the dissident equalled a traitor ${ }^{32}$.

Perhaps the most inspired and the best characterization of Eugen Lozovan belongs to the historian Georgeta Filitti, who saw him as a "passionate erudite scholar"33. Without any doubt he was one of the powerful voices of the Romanian intellectual dissent in exile although nowadays this aspect of his biography is almost completely forgotten. His contributions to exposing the false realities sustained by the totalitarian regime back home presented some significance for the Romanian exile worldwide. Their importance is still to be appreciated and properly understood among the countless writings, audio and video recordings of the Romanian exile which already represent historical documents. Together with many other names of this Romanian dissent, the activity of Eugen Lozovan ensured the continuity of genuine intellectual values in almost complete opposition with the situation that existed in communist Romania. Even the polemics which he engaged in, the broadcasts at the French Radio station, his open sympathy towards the legionary movement and marshal Ion Antonescu or his anti-Semitic accents can and should be visualized as symptoms of freedom as it was perceived and understood at that time at least by a part of the exiled Romanian intellectuals ${ }^{34}$ - freedom of speech, of discussion, of ideas - and also as an expression of his fight against the

Stindardul XVI, no. 104 (September - November 1968): 2. See also Glose istorico-literare, pp. 8183 (De la Biafra la Rwanda) and pp. 84-85 (Bumbeşti-Livezeni).

32 See for this aspect the interview with Paul Goma, entitled Trădarea exilului [The exile's betrayal] and conducted by Radu Negrescu-Sutu in Paris, December 1999, accessible online at https://sitadeasa.wordpress.com/2006/06/17/tradarea-exilului/, accessed in June 2019.

33 Georgeta Filitti, „Un erudit pătimaș: Eugen Lozovan”, article accessible online at https://www.ziarulmetropolis.ro/un-erudit-patimas-eugen-lozovan/, accessed in June 2019.

${ }^{34}$ One must not forget that quite a number of these exiles were sympathizers of the far-right movement back in Romania or were even members of the Iron Guard. 
communist regime and ideology. This is only one of the reasons for hoping that sometime in the future it would be possible to have a complete critical edition with his texts published in "Stindardul". Another one would be the necessity of reconnecting the Romanian society to that part of the collective memory which the totalitarian regime tried to deny and to erase. However, this is a work in progress and the nowadays situation is not necessarily optimistic. Next to other names, Eugen Lozovan represents a reference point for all those who might want to get a better grip of an intellectual exile which defied the oppression and the totalitarian propaganda.

\section{References:}

„Bumbeşti-Livezeni.” Stindardul XVI, no. 104 (September - November 1968), 2;

„Conu Iancu \& Co." Stindardul X, no. 64/65 (August - September 1962), p. 2;

Faur, Elena, Bogdan Harhătă, Nicolae Mocanu, coord. „Profil bibliografic Eugen Lozovan (2 mai 1929 - 3 decembrie 1997)", Dacoromania, new series XVIII, no. 2 (Cluj-Napoca, 2013): 148-181.

Filitti, Georgeta. Un erudit pătimaș: Eugen Lozovan, article accessible online at https://www.ziarulmetropolis.ro/un-erudit-patimas-eugen-lozovan/, accessed in June 2019;

Ierunca, Virgil. "Năpasta", Cuvântul în exil 6 (November 1962);

Interviu cu scriitorul Virgil Ierunca din Arhiva Grupului de Istorie Orală al Radio România, interview conducted by Octavian Silvestru, accessible online at http://arhiva.rador.ro/info4.shtml?cat=1281\&news=338665, accessed in June 2019;

Ionescu, Dan. „Images du prince Dragoş dans les manuscrits de Moldavie au XVIII siècle”. Revue des Etudes Sud-Est Européenes XIV, no. 4 (Octobre - Décembre 1976): 619-646.

Ioniţă, Sorin Gabriel. „Presa exilului românesc - componentă a patrimoniului național (1975-1989)." New Europe College Petre Țuțea Program Yearbook 20072008 (Bucharest, 2008);

Lozovan, Eugen. „Comemorarea lui Ion Bianu”, Jurnalul literar. New series XVII, no. 7-12 (April - May - June 2006);

Idem. Glose istorico-literare. Publicate în revista "Dorul", în anul 1994. Aalborg, 1994;

Idem. „Pe culmile descreerării”, Stindardul XXI, special edition, no. 124 B (July 1973).

Mirea, O.I. „Nelegiurea Sadoveanului.” Stindardul. No. 10-11 (June - July 1954);

Miron, Paul. Măsura urmelor. Timişoara, 2000;

Oprişan, I. „Repere biografice”, in Eugen Lozovan, Dacia Sacra. Edition, biographical reference points, and profile sketch by I. Oprişan. Translation from English and French by Mihai Popescu. Second edition. Bucharest, 2005, 247-252; 
88 | Revista Română de Studii Baltice şi Nordice / The Romanian Journal for Baltic and Nordic Studies 11 (1)

Pelin, Mihai. „Adversarul lui Iisus”. Adevărul literar şi artistic XI, no. 628 (6 August 2002);

Petreu, Marta. De la Junimea la Noica. Studii de cultură românească. Iaşi, 2011;

Polito, Paola. „Eugen Lozovan 1929-1997”. Revue Romane 33, 1 (1998): 4-6.

Preda, Cristian. Introducere în ştiința politică, Iaşi, 2013;

„Puţin îmi pasă de Biafra." Stindardul XVI, no. 104 (September - November 1968);

„Rusia împotriva Europei." Stindardul I, no. 2 (1953).

Sasu, Aurel. Dicționarul biografic al literaturii române, vol. I - A-L. Piteşti, 2006;

Spinei, Victor. Reprezentanţi de seamă ai istoriografiei şi filologiei româneşti şi mondiale. Brăila, 1996.

Totok, William and Elena-Irina Macovei. Intre mit şi bagatelizare. Despre reconsiderarea critică a trecutului, Ion Gavrilă Ogoranu şi rezistența armată anticomunistă din România. Iaşi, 2016;

„Trădarea exilului”. Interview with Paul Goma conducted by Radu Negrescu-Suțu in Paris, December 1999, accessible online at https://sitadeasa.wordpress.com/2006/06/17/tradarea-exilului/, accessed in June 2019;

Zamfirescu, Dinu. Cârtiţele Securității. Agenți de influenţă din exilul românesc. Iaşi, 2013. 